\title{
Does it pay to pay performance fees? Empirical evidence from Dutch pension funds
}

Citation for published version (APA):

Broeders, D. W. G. A., van Oord, A., \& Rijsbergen, D. R. (2019). Does it pay to pay performance fees? Empirical evidence from Dutch pension funds. Journal of International Money and Finance, 93, 299-312. https://doi.org/10.1016/j.jimonfin.2019.02.010

Document status and date:

Published: 01/05/2019

DOI:

10.1016/j.jimonfin.2019.02.010

Document Version:

Publisher's PDF, also known as Version of record

Document license:

Taverne

Please check the document version of this publication:

- A submitted manuscript is the version of the article upon submission and before peer-review. There can be important differences between the submitted version and the official published version of record.

People interested in the research are advised to contact the author for the final version of the publication, or visit the DOI to the publisher's website.

- The final author version and the galley proof are versions of the publication after peer review.

- The final published version features the final layout of the paper including the volume, issue and page numbers.

Link to publication

\footnotetext{
General rights rights.

- You may freely distribute the URL identifying the publication in the public portal. please follow below link for the End User Agreement:

www.umlib.nl/taverne-license

Take down policy

If you believe that this document breaches copyright please contact us at:

repository@maastrichtuniversity.nl

providing details and we will investigate your claim.
}

Copyright and moral rights for the publications made accessible in the public portal are retained by the authors and/or other copyright owners and it is a condition of accessing publications that users recognise and abide by the legal requirements associated with these

- Users may download and print one copy of any publication from the public portal for the purpose of private study or research.

- You may not further distribute the material or use it for any profit-making activity or commercial gain

If the publication is distributed under the terms of Article $25 \mathrm{fa}$ of the Dutch Copyright Act, indicated by the "Taverne" license above, 


\title{
Does it pay to pay performance fees? Empirical evidence from Dutch pension funds
}

\author{
Dirk W.G.A. Broeders ${ }^{\mathrm{a}, \mathrm{b}, *}$, Arco van Oord ${ }^{\mathrm{a}}$, David R. Rijsbergen ${ }^{\mathrm{a}}$ \\ ${ }^{a}$ De Nederlandsche Bank, the Netherlands \\ ${ }^{\mathrm{b}}$ Maastricht University, the Netherlands
}

\section{A R T I C L E I N F O}

\section{Article history:}

Available online 6 February 2019

\section{JEL classification:}

G11

G12

G23

Keywords:

Pension funds

Asset management

Performance fees

Investment costs

\begin{abstract}
A B S T R A C T
We analyze the relation between investment returns and performance fees for 218 Dutch occupational pension funds with an average total of 1090 billion euro in assets under management from 2012 to 2017. Our dataset is free from self-reporting biases and includes total return, excess return and performance fees for six major asset classes. We find no statistical evidence that the returns of pension funds that pay performance fees to asset managers for active investing are significantly higher or lower than the returns of pension funds that do not pay performance fees. This is true for most asset classes and robust if we correct for risk. We also document that large and more specialized pension funds pay less performance fees for a given level of excess return in alternative asset classes such as hedge funds and private equity. This is possibly the result of better negotiation power due to their larger scale or higher level of expertise.
\end{abstract}

(c) 2019 Elsevier Ltd. All rights reserved.

\section{Introduction}

Performance-based investment fees are increasingly important for the pension fund industry. Pension funds typically pay performance fees for active investment strategies and alternative asset classes such as investments in hedge funds and private equity. Many pension funds increased their allocation to these alternative asset classes in recent years (Malkiel, 2013). The Willes Towers Watson Global Pension Asset Study reveals that the 16 largest pension markets in the world increased the allocation to alternative asset classes from about 4 percent in 1997 to 25 percent in 2018 (Willis Towers Watson, 2018). The reasons for this increased allocation to alternative asset classes are higher return expectations, better portfolio diversification and in some cases a better match with the pension fund's liabilities.

The higher allocation to alternative asset classes has led to an increase in performance fees expenses. The annual performance fees paid by Dutch pension funds, for example, almost doubled from EUR 1.1 billion to EUR 2.0 billion between 2012 and 2017. As a percentage of total investment costs, performance fees rose from 24.8 to 32.9 percent in the same period. The present value of these fees over the long term represent the transfer of a significant fraction of the pension fund's wealth from beneficiaries to asset managers. This is underlined by Sharpe (2013) who documents that small differences in

\footnotetext{
The authors would like to thank an anonymous referee, Rob Bauer, Bart Bos, Esther Eiling, Janko Gorter, Paul Hilbers, Klaas Knot, André Lucas, Theo Nijman, Ton Vorst and seminar participants at De Nederlandsche Bank for useful comments and suggestions. The views expressed in this article are our own and do not necessarily reflect those of DNB or Maastricht University.

* Corresponding author.

E-mail address: d.w.g.a.broeders@dnb.nl (D.W.G.A. Broeders).
} 
investment costs compound to dramatic effects on terminal wealth. Paying performance fees, however, could well be economically rational if they enable pension funds to enhance their overall net performance by recovering these costs with superior returns or higher diversification benefits.

From a theoretical perspective, performance fees can be a valuable mechanism to minimize the principal-agent conflict between pension funds and asset managers. Fees align the asset managers' incentives with the pension fund's goal by directly linking the managers' rewards to performance (Starks, 1987). ${ }^{2}$ This should increase the effort from asset managers and thus translate into higher investment returns for the pension fund (Ackermann et al., 1999). However, performance fees also come with several drawbacks. For one, asset managers tend to receive the same fee whether performance comes from skill or luck. Moreover, they create a skewed (call-option like) incentive structure as the asset manager typically only profits from positive excess returns, but does not suffer from losses. This may incentivize asset managers to take excessive risks in an attempt to generate high returns (Goetzmann et al., 2003; Kahn et al., 2006). To counter some of these disadvantages, most investment mandates with performance fees include provisions such as high watermarks or clawbacks (French, 2008).

A better understanding of the relation between performance-based fees and investment returns is important for pension funds, as this will help improve their asset allocation and contracting process. Little empirical evidence, however, is available on how performance fees paid by pension funds relate to investment performance. There is a vast literature on whether pension funds are able to outperform their benchmarks (e.g., Lakonishok et al., 1992; Coggin et al., 1993; Blake et al., 1999; Andonov et al., 2012). And there are also papers on the investment cost structure of pension funds (e.g., Bikker and De Dreu, 2009; Bauer et al., 2010, Broeders et al., 2016). However, to the best of our knowledge there are no papers that examine the relation between performance fees and the net investment performance of pension funds for different asset classes. This can primarily be attributed to the absence of sufficiently reliable and detailed data.

This paper adds to the existing literature by empirically examining the relation between the investment performance of pension funds and the performance fees they pay for different asset classes. We examine three main questions. First, we investigate if paying performance fees contributes to higher net (after-fee) total returns or net excess returns. This shows whether it pays for pension funds to pay performance fees. Second, we examine for what type of gross (before-fee) return, excess or total return, pension funds primarily pay performance fees. This provides us with more insight into the mandates pension funds typically give to their asset managers. Third, we test whether large pension funds and pension funds with more specialization in their investment portfolio pay less performance fees per basis point of gross excess return. This enables us to examine whether large or more specialized pension funds are able to operate more efficiently by negotiating more profitable contracts with asset managers. To answer these research questions, we have panel data containing investment returns, benchmark returns and costs for 218 Dutch pension funds between 2012 and 2017.

The Dutch system provides an interesting case study as it is well-developed and relatively large in terms of size. Dutch pension funds allocate their money to a wide variety of asset classes given the absence of quantitative investment restrictions. Dutch pension funds do have to follow the so-called prudent person rule, which demands that pension funds invest in the interest of their beneficiaries, taking into account sufficient liquidity, diversification and quality of the investment portfolio. Our findings, however, are also relevant for other countries where pension funds face no quantitative investment limits to invest in alternative asset classes that typically employ performance-based fees, such as hedge funds and private equity. These include European countries such as Ireland and the United Kingdom, as well as non-European countries such as Australia, Canada and the United States. ${ }^{3}$

The dataset is free from self-reporting biases and highly detailed, making this paper the first to thoroughly distinguish between returns and costs for different asset classes. We have information at the total portfolio level, as well as for six asset classes that pension funds invest in, namely fixed income, equities, real estate, private equity, hedge funds and commodities. We can further decompose these classes into thirteen sub-asset classes. In addition, we subject our findings to a range of robustness checks - including bootstrapped standard errors and correction for risk.

We document the following key findings. First, we find that the net returns of pension funds that pay performance fees to asset managers are not significantly higher or lower than the net returns of pension funds that do not pay performance fees. There is, however, one exception. Pension funds that pay performance fees to hedge funds report 2.3 basis points higher net excess returns on average. This positive effect on net excess returns disappears, however, when we correct for risk. Second, we observe that performance fees primarily relate to gross excess returns for equities, real estate and hedge funds. Pension funds pay 29.1 basis points in performance fees for every 100 basis points of gross excess return in hedge funds, while this ratio is 2.1 for both equity and real estate. For private equity, performance fees primarily correspond to gross total return. Investment mandates for private equity thus appear more focused on absolute returns than on outperforming some benchmark. Third, we find that large and more specialized pension funds are able to realize more profitable mandates with their asset managers, possibly as a result of better negotiation power due to their large scale or high level of expertise. Also large pension funds might be more interesting for asset managers to have as clients because of

\footnotetext{
1 This would require some form of manager/fund selection skills from pension funds as Sharpe (1991) and French (2008) show that active management is a zero sum game before cost indicating that the aggregate alpha is zero and only a few funds are able to produce alpha. After costs, French shows that active management is a negative sum game.

2 Starks (1987) shows that problems arise in the relationship between investors and asset managers due to the presence of moral hazard and the absence of costless and full information.

${ }^{3}$ Similar to the Netherlands, these countries have no quantitative investment restrictions as part of the prudent person rule.
} 
reputational reasons. For large pension funds, this is the case for hedge funds. A tenfold increase in hedge fund investments, for instance, correlates with 6.2 basis points less performance fees per 100 basis points in gross excess return. For specialization, we find a significant effect for private equity and hedge funds. Pension funds that increase their allocation to private equity by 1 percentage point pay 0.32 basis points less fees per 100 basis points gross excess return. For hedge funds, this reduction is 0.30 basis points.

This paper relates to three streams of literature. The first stream concentrates on pension fund performance and typically concentrates on the question whether pension funds are able to outperform their benchmark or the general market by selecting outperforming asset managers and investments. The academic evidence for that is mixed. Several studies find that pension funds, on average, are unable to outperform external benchmarks (e.g., Beebower and Bergstrom 1977; Ippolito and Turner, 1987; Lakonishok et al., 1992; Coggin et al., 1993). ${ }^{4}$ Lakonishok et al. (1992), for example, analyze the investment performance of U.S. pension funds and find that their equity investments underperform the S\&P 500 index by 260 basis points on an annual basis. Blake et al. (1999) and Blake et al. (2013) study the asset allocations of U.K. pension funds and also find little evidence for market timing skills. Huang and Mahieu (2012) use an alternative risk adjusted performance measure, the so-called $z$-score, and find that Dutch pension funds are unable to consistently outperform their self-selected benchmarks. Gerritsen (2016) examines the equity investments of Dutch pension funds and also concludes that they are unable to outperform either their benchmarks or the general market index. There are, on the other hand, also studies that find evidence of outperformance by pension funds. Using the CEM pension fund dataset, Bauer et al. (2010) study domestic equity investments of U.S. pension funds and document a positive and statistically significant net performance on a risk-adjusted basis. Andonov et al. (2012) examine different components of active management - asset allocation, market timing and security selection - for U.S. pension funds. They provide evidence that pension funds are able to beat the market as well as their benchmark, and find that all three components contribute to this outperformance. ${ }^{5}$ Although some of these papers relate performance to investment costs (e.g., Ippolito and Turner, 1987; Bauer et al., 2010; Andonov et al., 2012), they are not able to directly investigate the relation between performance and performance-based fees.

The second stream of literature studies the impact of investment fees on performance from the asset manager's perspective. These papers typically focus on (equity) mutual funds, private equity and hedge funds. For mutual funds, most studies document a robust negative relation between fees and net performance (Carhart, 1997; Fama and French, 2010), although Elton et al. (2003) observe that funds with symmetric fee structures report positive alphas. For hedge funds and private equity, the empirical evidence is mixed, although there appears to be a slight tendency towards studies that document a positive relation between performance fees and investment performance. Several studies (e.g., Ackermann et al., 1999; Agarwal et al., 2009; Ibbotson et al., 2011) report that hedge funds with higher performance fees typically earn higher investment returns. Brown et al. (1999), on the other hand, document that high fee funds perform no better than those with lower fees. Jennings and Payne (2016) investigate the diversification benefits of (fund of) hedge funds after fees and find that the higher fees of these strategies overwhelm the diversification benefit. In the private equity sector, Gompers and Lerner (1999) find no relation between performance fees and investment returns. Robinson and Sensoy (2013), however, study buyout and venture capital private equity funds and find that fund managers (i.e., general partners) with higher compensation earn their fees by generating higher gross performance.

The third stream of academic literature that this paper relates to concentrates on the operational efficiency of pension fund investment costs and the increased drive for more transparency on cost structures. Several papers examine pension fund investment costs and document strong evidence for economies of scale at the pension fund level (e.g., Bauer et al., 2010; Bikker and De Dreu, 2009) as well as for several asset classes that pension funds invest in (Broeders et al., 2016). The observed economies of scale are in line with academic evidence for the mutual fund sector (Malkiel, 2013; Indro et al., 1999). Moreover, the economies of scale in the pension fund industry appear primarily driven by management costs, and not by performance-based fees (Broeders et al., 2016). For equities, private equity and hedge funds, Broeders et al. (2016) find that larger Dutch pension funds pay higher performance fees than their smaller counterparts. In addition, there are many papers promoting full transparency of institutional investors regarding their investment costs (Keim and Madhavan, 1998; Barber et al., 2005).

The remainder of this paper is as follows. Section 2 describes the data and the variables we use in our analysis. Section 3 presents the methodology. Section 4 shows the empirical results of whether performance fees contribute to higher net returns, whereas Section 5 presents the robustness checks. The conclusions are set out in the final section.

\section{Data}

We use an unbiased panel dataset with investment-related data of 218 Dutch pension funds between 2012 and 2017. The dataset contains pension fund-specific (net and gross) investment returns, self-reported benchmark returns and investment costs. The investment costs can be decomposed in performance fees and management costs. The investment-related data are

\footnotetext{
${ }^{4}$ Also note that there are several studies that investigate persistence in the performance of pension funds. There is, however, little consensus regarding persistence in pension fund performance (Blake et al., 2013).

${ }^{5}$ The lack of consensus regarding the ability of pension funds to provide outperformance is in line with the large body of literature regarding mutual fund performance. Most studies conclude that mutual funds underperform their benchmark (e.g., Jensen, 1968, Malkiel, 1995, Carhart, 1997, Fama and French, 2010), whereas some studies find that subgroups of fund managers are able to produce outperformance net-of-costs (e.g., Kosowski et al., 2006).
} 
available at the pension fund level, as well as for the following six broad asset classes: fixed income, equity, real estate, private equity, hedge funds and commodities. We also have data on the actual allocation to these asset classes and are able to further decompose these asset classes into thirteen sub-classes with regard to fixed income (i.e., government bonds, inflation linked bonds, mortgages, corporate bonds and cash), equities (i.e., mature markets and emerging markets) and real estate (i.e., direct real estate, listed real estate and indirect real estate). For fixed income securities, we can also differentiate between credit rating classes. In addition, we use other pension fund-specific variables in the analysis, including pension fund size (assets under management), asset class size and the level of specialization in the investment portfolio (see Broeders et al., 2016).

The dataset in this paper contains a variety of pension fund sizes and types. The total assets under management of the pension funds in the dataset rises from approximately 856 billion euro in 2012 to 1291 billion euro in 2017. On average, this amounts to roughly 98.5 percent of the total assets under management for all Dutch pension funds during the six years in our sample period. The data are collected by De Nederlandsche Bank (DNB), the prudential supervisor of Dutch pension funds. The dataset does not suffer from self-reporting biases as all pension funds in the Netherlands are obliged to submit their investment returns, costs and asset allocation to DNB. We consider the data quality to be high as they are validated by the pension fund's external auditor.

\subsection{Definition of variables}

The key dependent variables in our analysis are investment returns and performance fees. We measure returns and fees at the pension fund level as well as for each asset class separately. In addition, we investigate the impact of pension fundspecific characteristics.

\subsubsection{Investment returns}

Pension funds report their annual investment returns in percentage points on a yearly basis. ${ }^{6}$ So we define the annual investment return as $R_{j, k, t}$ for pension fund $j$, where $t$ denotes the year in the sample (2012-2017) and $k$ represents the asset classes, which include fixed income, equity, real estate, private equity, hedge funds and commodities. Mark that this annual return $R_{j, k, t}$ is the aggregate return per asset class $k$ and may be the result of several returns on different mandates and investment funds of pension fund $j$ in asset class $k$. The dataset does not allow to disentangle different mandates. If $k$ is suppressed it refers to the pension fund's total portfolio.

Our dataset allows us to differentiate between types of investment returns. The dataset contains annual gross total returns $\left(R_{j, k, t}^{G, T}\right)$ as well as benchmark returns $\left(B R_{j, k, t}\right)$ at the portfolio level and for the separate asset classes. The reported benchmarks are selected and reported by the pension funds themselves and allow us to construct gross excess returns $\left(R_{j, k, t}^{G, E}\right)$ by subtracting the benchmark return from the reported investment return. In addition, we are able to construct net total returns $\left(R_{j, k, t}^{N, T}\right)$ and net excess returns $\left(R_{j, k, t}^{N, E}\right)$ by subtracting the investment costs $\left(C_{j, k, t}\right)$ from the gross total returns and gross excess returns. Investment costs is the sum of management costs and performance fees. See the overview below for the description of all return variables.

\begin{tabular}{ll}
\hline Return/cost variable: & Description: \\
\hline Gross total return & $R_{j, k, t}^{G, T}$ \\
Gross benchmark return & $B R_{j, k, t}^{G, T}$ \\
Gross excess return & $R_{j, k, t}^{G, E}=R_{j, k, t}^{G, T}-B R_{j, k, t}$ \\
Investment cost & $C_{j, k, t}, R_{j, T}^{N, T}=R_{j, k}^{G, T}-C_{j, k, t}$ \\
Net total return & $R_{j, k, t}^{N, k}=R_{j, k, t}^{G, E}-C_{j, k, t}=R_{j, k, t}^{G, T}-B R_{j, k, t}-C_{j, k, t}$ \\
Net excess return & \\
\hline
\end{tabular}

\subsubsection{Investment costs}

Investment costs include all costs incurred in the investment management process, from strategy, implementation to monitoring the portfolio. In our analysis, we differentiate between two key components, namely management costs and performance fees. We define management costs as the cost of having assets professionally managed which includes the fees paid for security selection, execution and disclosure. Examples of management costs include the costs of trading facilities, financial research and risk management (Bikker and De Dreu, 2009). Management costs structures are typically a percentage of assets under management. Performance fees, on the other hand, are contingent on a specific performance objective (e.g., Drago et al., 2010). Finally, we are not able to separately investigate explicit trading costs (i.e. direct costs of trading such as broker commissions) and implicit trading costs (i.e. indirect costs such as the price impact of trades), as pension funds are

\footnotetext{
${ }^{6}$ Note that pension funds also report their investment returns on a quarterly basis.
} 
not obliged to report these trading costs. ${ }^{7}$ Trading costs are however included in our return definition, as trading costs are already deducted in the gross returns that pension funds report. We also note that pension funds manage their investments in different ways. They can choose to manage their investments internally or externally. We do not elaborate on these differences as our dataset does not distinguish between internal and external asset management.

\subsubsection{Performance fees}

Performance fees come in many forms and are common in different asset classes, such as private equity, hedge funds and specialized equity funds. In practice, they are often combined with fixed management fees. Hedge funds typically employ a fee structure that consists of a (1.5 percent) fixed management fee and a (20 percent) performance fee (Ibbotson et al., 2011), while private equity funds generally employ a constant percentage of committed capital in combination with performance-based fees through carried interest (Metrick and Yasuda, 2010). The performance fee can be charged on any positive return, on returns above some benchmark or on returns above some fixed hurdle rate. ${ }^{8}$ Underlying all, however, is the fact that the payment of the fee is contingent upon the performance of the asset manager. Although we have no data on the exact way performance fees are derived by the pension funds in our sample, we measure performance fees $P F$ for pension fund $j$ in basis points as the fee in year $t$ over the average assets under management (AUM) in that year in the following manner:

$$
P F_{j, k, t}=\frac{\text { Performance Fees }_{j, k, t}}{\frac{1}{4} \sum_{i=1}^{4} A U M_{j, k, t, i}}
$$

The fees are reported on an annual basis, whereas the assets under management are reported for every quarter (indicator $i$ ).

\subsubsection{Pension fund-specific characteristics}

Several academic papers document that size matters for pension fund performance. Huang and Mahieu (2012) find that large pension funds outperform smaller ones. Gerritsen (2016) concludes that large pension funds realize higher equity returns than their smaller counterparts. The current literature presents several explanations, such as more negotiation power, better monitoring of asset managers, more expertise in selecting superior asset managers and economies of scale in investment costs (e.g., Andonov et al., 2012; Dyck and Pomorski, 2011; Broeders et al., 2016). In addition, Andonov et al. (2012) argue that the relation between size and performance depends on the asset class. Large pension funds realize economies of scale in alternative asset classes due to better negotiation power and more available resources for monitoring these investments. At the same time, large pension funds suffer from liquidity constraints in public equity and fixed income markets leading to diseconomies of scale. Dyck and Pomorski (2011) also find strong evidence for economies of scale in alternative asset classes, both in gross returns and costs. Most notably in real estate and private equity, where large funds have access to more co-investment opportunities and are better able to identify the best performing managers. It is therefore interesting to examine whether size influences the relation between investment returns and performance fees. We measure the size of pension funds by either the logarithmic value of the average total assets under management in a given year or by the $\log$ of the average assets under management in a given year in a specific asset class. We also study whether more specialized pension funds - i.e. pension funds that invest relatively more in a specific asset class - pay relatively less performance fees for a given level of return. Specialization is measured by dividing the average assets under management in a given year invested in a particular asset class by average total assets under management in that year.

\subsection{Descriptive statistics}

Table 1 shows the descriptive statistics. Panel A discloses the net total returns after fees and costs. The average annual total net portfolio return over the six years in the sample equals 9.12 percent. This is the equally weighted return across all pension funds for the full sample period. There is quite some dispersion in the sample. The 10th percentile shows a net return of -1.10 percent and the net return in the 90th percentile is 21.64 percent. The wide dispersion occurs across all asset classes. For instance, the full sample difference between the best and lowest performance in fixed income is 32.96 percentage points (ranging from +27.54 to -5.42 percent). Equities is the best performing asset class and shows the lowest dispersion across pension funds.

Panel B presents the net excess returns. These net excess returns are reported in annual basis points and derived by subtracting the (self-reported) benchmark returns from the realized net returns. The annual total net excess return across all pension funds over the full sample period equals 18.2 basis points. ${ }^{9}$ Yet, the data reveal a significant amount of variation. The 10 percent best performing pension funds report 189.3 or more basis points excess return. For the lowest performing pen-

\footnotetext{
${ }^{7}$ Some pension funds voluntarily report transaction costs separately. Whilst transaction costs are important, we exclude them from our analysis because the number of pension funds reporting these costs in our sample is too few. For the importance of transaction or trading costs in an institutional context, see Keim and Madhavan (1998) and Bikker et al. (2007).

${ }^{8}$ Metrick and Yasuda (2010) find that hurdle rates in the private equity domain are more prevalent among buyout funds than venture capital funds.

${ }^{9}$ In 2015 reporting templates changed with respect to currency overlay. Before 2015 the total net (excess) returns exclude the return on the currency overlay, while from 2015 onwards the currency overlay is included. For 2015 and later years this implies that the total net (excess) returns may differ from the weighted average net (excess) returns of the returns on the different asset classes, because the asset class returns always exclude currency overlay.
} 
Table 1

Statistics on pension fund investment returns.

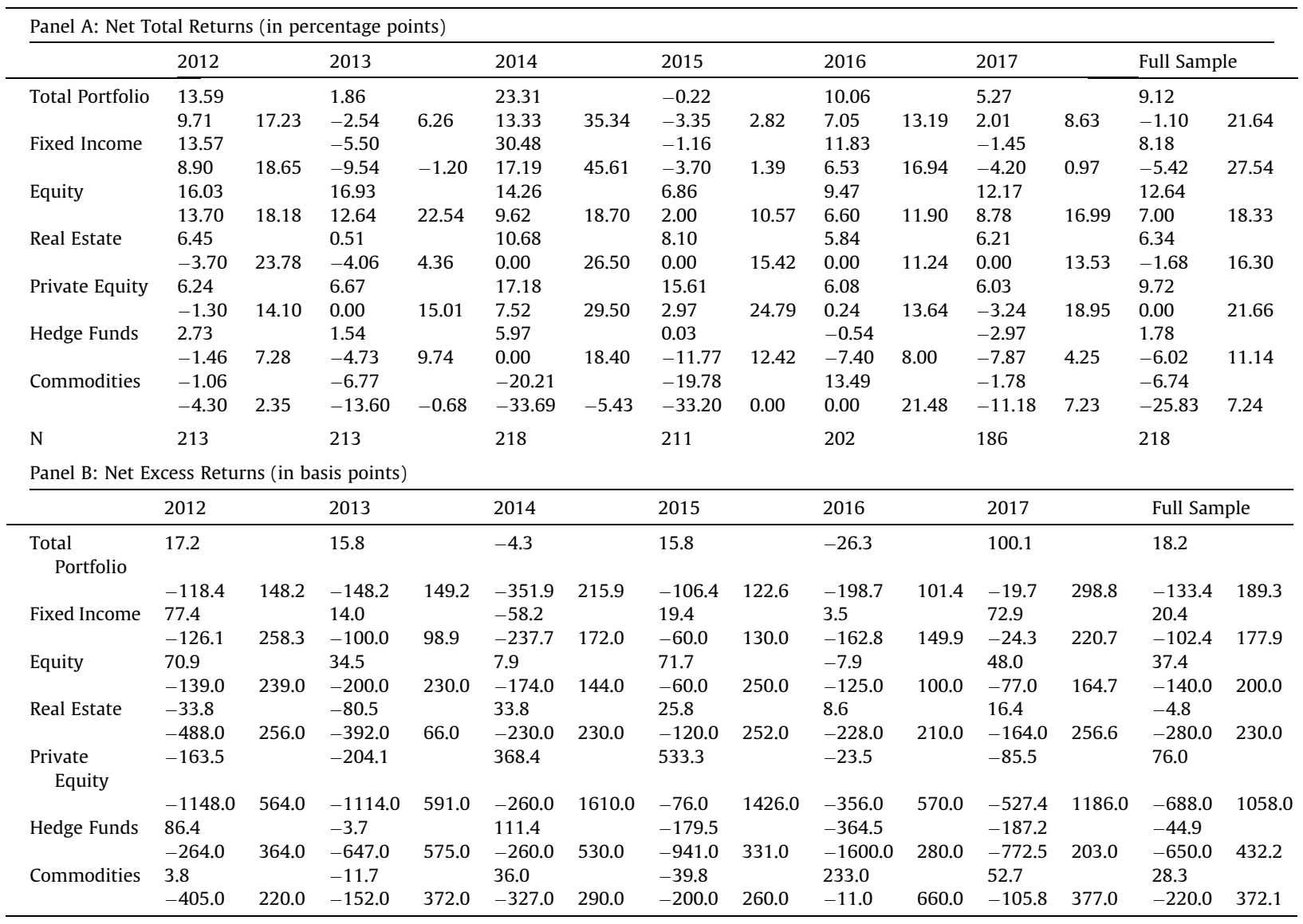

Table 1 presents an overview of the main statistics on the pension fund investments returns for all years of the sample period (2012-2017). Panel A reports the mean net time weighted investment total returns, as well as the minimum (10th percentile) and maximum (90th percentile) observations one row lower. These net total returns are expressed as annual percentage points and derived by deducting all investment costs from gross returns. The full sample return is the equally weighted average across all pension funds for all years. Panel A also report the number of pension funds in the sample ( $\mathrm{N}$ ). Panel B displays the net excess investment returns in basis points, which are represented by net returns minus benchmark returns. The benchmark returns are selfreported by the pension funds.

sion funds the excess returns is -133.4 basis points or less. Private equity has the highest mean excess return with 76.0 basis points over the sample, but the variation is extremely high. Note that the benchmark returns are self-reported and may therefore not necessarily equal standard, broad accepted benchmarks such as the MSCI World index for equities. An advantage of the self-selected benchmark is that they are tailored to the specific investment beliefs of pension funds (Broeders and De Haan, 2018). E.g., if a pension fund excludes a specific industry it may correct a standard benchmark for this. The dataset, however, contains no details on the exact composition of benchmarks reported by the individual pension funds. Our statistics for net excess returns are comparable to Andonov et al. (2012) who report a mean of 31 basis points. We find 20 basis points net excess returns for fixed income where Andonov et al. (2012) report 42 basis points. Furthermore, we find 37 basis points for equities where Andonov et al. (2012) report 28 basis points.

Table 2 presents the details on performance fees, which are expressed in annual basis points. For the full sample, we find an annual equally weighted mean performance fee of only 2.9 basis points. The lower boundary is 0 basis points, while the top 10 percent pension funds with the highest performance fees pay more than 10.1 basis points per year on average. The highest average performance fees are paid for investing in private equity and hedge funds, with 76.2 and 82.9 basis points respectively. The variation in performance fees over time is sometimes significant. The average performance fee for private equity rose from 22.1 basis points in 2012 to 116.0 basis points in 2017. In some cases the 90th percentile is lower than the mean. This happens if many pension funds report zero performance fees for that asset class in that year. The distribution between pension funds that pay performance fees and those that do not during the six years in our sample period is even for most asset classes. 
Table 2

Statistics on pension fund performance fees.

\begin{tabular}{|c|c|c|c|c|c|c|c|c|c|c|c|c|c|c|}
\hline & 2012 & & 2013 & & 2014 & & 2015 & & 2016 & & 2017 & & Full S & nple \\
\hline \multirow[t]{2}{*}{ Total Portfolio } & 3.0 & & 3.3 & & 2.9 & & 2.9 & & 2.3 & & 3.3 & & 2.9 & \\
\hline & 0.0 & 10.1 & 0.0 & 10.7 & 0.0 & 9.5 & 0.0 & 10.8 & 0.0 & 8.6 & 0.0 & 9.9 & 0.0 & 10.1 \\
\hline \multirow[t]{2}{*}{ Fixed Income } & 1.1 & & 0.8 & & 0.4 & & 0.2 & & 0.2 & & 0.3 & & 0.5 & \\
\hline & 0.0 & 2.0 & 0.0 & 1.6 & 0.0 & 0.3 & 0.0 & 0.5 & 0.0 & 0.0 & 0.0 & 0.4 & 0.0 & 0.6 \\
\hline \multirow[t]{2}{*}{ Equity } & 3.4 & & 2.0 & & 1.6 & & 2.5 & & 1.6 & & 2.0 & & 2.2 & \\
\hline & 0.0 & 8.7 & 0.0 & 7.2 & 0.0 & 5.0 & 0.0 & 5.5 & 0.0 & 4.6 & 0.0 & 5.6 & 0.0 & 6.6 \\
\hline \multirow[t]{2}{*}{ Real Estate } & 1.9 & & 3.2 & & 3.2 & & 3.7 & & 1.9 & & 4.0 & & 3.0 & \\
\hline & 0.0 & 1.3 & 0.0 & 7.3 & 0.0 & 7.2 & 0.0 & 11.1 & 0.0 & 7.3 & 0.0 & 8.8 & 0.0 & 7.3 \\
\hline \multirow[t]{2}{*}{ Private Equity } & 22.1 & & 57.3 & & 102.0 & & 91.7 & & 67.1 & & 116.0 & & 76.2 & \\
\hline & 0.0 & 98.5 & 0.0 & 219.7 & 0.0 & 248.1 & 0.0 & 256.1 & 0.0 & 209.6 & 0.0 & 303.0 & 0.0 & 235.5 \\
\hline \multirow[t]{2}{*}{ Hedge Funds } & 105.1 & & 82.7 & & 75.6 & & 78.0 & & 51.1 & & 85.7 & & 82.9 & \\
\hline & 0.0 & 201.8 & 0.0 & 189.9 & 0.0 & 162.8 & 0.0 & 123.9 & 0.0 & 117.7 & 0.0 & 159.1 & 0.0 & 176.3 \\
\hline \multirow[t]{2}{*}{ Commodities } & 1.8 & & 1.3 & & 0.6 & & 0.2 & & 1.1 & & 6.2 & & 1.5 & \\
\hline & 0.0 & 6.1 & 0.0 & 0.0 & 0.0 & 0.4 & 0.0 & 0.0 & 0.0 & 5.3 & 0.0 & 9.7 & 0.0 & 1.4 \\
\hline
\end{tabular}

Table 2 displays the main descriptive statistics on the performance fees paid by pension funds for all years of the sample period (2012-2017). The row "Total Portfolio" reports the equally weighted mean performance fees at the portfolio level, while the table also presents the performance fees for six separate asset classes. The minimum (10th percentile) and maximum (90th percentile) observations are reported one row lower for all asset classes. The performance fees are expressed as annual basis points of the average assets under management in the applicable period.

\section{Methodology}

This section describes the methodology for examining the three research questions on the relation between investment performance of pension funds and the performance fees they pay. First, we examine the relation between performance fees and net returns. Second, we analyze the drivers of performance fees. Third, we focus on the impact of pension fund characteristics on fees.

\subsection{Performance fees and net returns}

We use a cross-sectional regression model to examine our first research question whether pension funds that pay performance fees are able to earn higher net total or excess returns. We run the following model to explain the net investment returns $R$ for pension fund $j$ in year $t$ :

$$
\begin{aligned}
& R_{j, k, t}=\beta_{1} \text { Paying Fees } \text { Fe, }_{j, t-1}+\beta_{2} \log \left(\text { Size }_{j, k, t}\right)+\beta_{3} \text { Spec }_{j, k, t}+ \\
& \sum_{t^{*}=2012}^{2017} I\left(t=t^{*}\right)\left(\beta_{4, t^{*}} \text { DUR }_{F I . j, k, t}+\beta_{5, t^{*}} \text { DUR }_{0, j, k, t}+X_{j, k, t} \beta_{6, k, t^{*}}+Y_{j, k, t} \beta_{7, k, t^{*}}\right)+\varepsilon_{j, k, t}
\end{aligned}
$$

where $R$ represents either the net total return $\left(R_{j, k, t}^{N, T}\right)$ or the net excess return $\left(R_{j, k, t}^{N, E}\right)$. Index $k$ indicates one of the six different asset classes, namely fixed income, equity, real estate, private equity, hedge funds or commodities. Index $k$ is suppressed if it refers to the pension fund's total portfolio. Paying Fees is a dummy variable that equals one if a pension fund pays performance fees in a given year and zero otherwise. To avoid endogeneity - as performance fees paid in year $t$ are dependent on the investment return in that same year $t$ - we lag this variable by one year $(t-1)$. As pension funds typically not change their policy on whether they pay performance fees or not on a yearly basis, the lagged variable still allows us to examine whether paying performance fees contributes to a higher net return. We also include Size which is either defined as the pension funds' average total assets under management in a given year or as the average amount that pension fund $j$ invests in a specific asset class in a given year. Spec represents the level of specialization by dividing the average assets under management in a particular asset class in a given year by the average total assets under management in that year. Note that specialization by definition is not a meaningful measure at the total portfolio level.

In addition, we include several variables in regression (1) to control for the impact of differences in asset allocation between pension funds (Broeders et al., 2016). For that, we include $I\left(t=t^{*}\right)$ as an indicator function that equals 1 if $t=t^{*}$ (i.e. years 2012 through 2017) and 0 when this is not the case. If no sub asset classes exist for asset class $k$ then the dummies represent the average return on asset class $k$ in year $t^{*}$. Within the indicator function, $D U R_{F I}$ is the duration contribution of the fixed income portfolio, while $D U R_{O}$ represents the duration contribution of fixed income derivatives. We define the duration contribution of fixed income as the part of a pension funds' total duration ascribable to its bond portfolio. In addition, we define the duration contribution of overlay as the incremental duration due to the interest rate overlay exposure of interest rate derivatives (Broeders et al., 2016). Both variables are measured in years and their coefficients $\left(\beta_{4, t^{*}}\right.$ and $\left.\beta_{5, t^{*}}\right)$ reflect the average interest rate changes in the sample years. $X$ is a vector of control variables that represent the pension fund's asset allocation (weights add up to one), where the coefficients for $\beta_{6, t^{*}}$ reflect the average return on the different sub-asset classes. $Y$ is a vector that reports the allocation within the fixed income portfolio to different credit rating classes. Note that the vector 
$Y$ and the duration variables are only included in the regressions for the total portfolio and fixed income. Finally, the error term is indicated by $\varepsilon$. All standard errors are White standard errors corrected for heteroskedasticity.

\subsection{Performance fees drivers}

Our second research question is whether performance fees are primarily driven by gross excess or by total returns. For this analysis we use a Tobit regression model. We solely observe positive performance fees in our dataset and a Tobit model takes account of the non-negative constraint of our key variable. ${ }^{10}$ We define the dependent variable $P F_{j, k, t}$ as the actual level of performance fees of pension fund $j$ in a given year $t$ for a given asset class $k$, andPF $F_{j, k, t}^{*}$ as the latent variable that represents the level of performance fees if it would not be constrained. As a result, we have the following equation:

$$
P F_{j, k, t}=\left\{\begin{array}{c}
P F_{j, k, t}^{*} \text { if } P F_{j, k, t}^{*}>0 \\
0 \text { if } P F_{j, k, t}^{*} \leq 0
\end{array}\right.
$$

As a first step we examine whether performance fees relate to gross excess returns as investors typically pay these type of fees for returns in excess of a pre-defined benchmark. For that, we use the following regression to explain the performance fees $P F$ for pension fund $j$ in year $t$ :

$$
P F_{j, k, t}^{*}=\beta_{1, k} I\left(R_{j, k, t}^{G, E}>0\right) R_{j, k, t}^{G, E}+\sum_{t^{*}=2012}^{2017} I\left(t=t^{*}\right) \beta_{t^{*}}+u_{j, k, t}
$$

where $R_{j, k, t}^{G, E}$ represents the gross excess return and $I\left(R_{j, k, t}^{G, E}>0\right)$ is an indicator function that equals 1 when the gross excess return is positive and 0 when it is negative. Index $k$ either represents the total portfolio level or one of the six different asset classes we distinguish: fixed income, equity, real estate, private equity, hedge funds and commodities. We also add six dummy variables for the years in our sample.

In addition, we test whether performance fees are related to gross total returns $R_{j, k, t}^{G, T}$ by including this variable in regression model (3):

$$
P F_{j, k, t}^{*}=\beta_{1, k} I\left(R_{j, k, t}^{G, E}>0\right) R_{j, k, t}^{G, E}+\beta_{2, k} I\left(R_{j, k, t}^{G, T}>0\right) R_{j, k, t}^{G, T}+\sum_{t^{*}=2012}^{2017} I\left(t=t^{*}\right) \beta_{t^{*}}+u_{j, k, t}
$$

In Tobit regression models, a change in $R_{j, k, t}^{G, E}$ has two effects, namely an effect on the mean of $P F_{j, k, t}^{*}$ given that it is observed (an increase in the level of performance fees paid) and an effect on the probability of $P F_{j, k, t}^{*}$ being observed (pension funds paying performance fees). In our analysis we focus on the conditional mean that represents the expected value of the actual level of performance fees, conditional on fees being positive $E\left(P F_{j, k, t} \mid 0<P F_{t}<\infty\right)$. In this setting, the estimation results indicate how a one unit change in an independent variable $\left(R_{j, k, t}^{G, E}\right.$ or $\left.R_{j, k, t}^{G, T}\right)$ affects the observed performance fee, given that it is positive.

\subsection{Pension fund specific characteristics}

With the third research question we investigate whether pension fund specific characteristics influence the relation between performance fees and gross excess returns. We specifically look at pension fund size and the level of specialization. For that, we extend regression model (3) as follows:

$$
\begin{aligned}
& P F_{j, k, t}=\beta_{1, k} \log \left(\operatorname{Size}_{j, k, t}\right)+\beta_{2, k} \operatorname{Spec}_{j, k, t}+I\left(R_{j, k, t}^{G, E}>0\right)\left(\beta_{3, k}+\beta_{4, k} \log \left(\operatorname{Size}_{j, k, t}\right)+\beta_{5, k} \operatorname{Spec}_{j, k, t}\right) R_{j, k, t}^{G, E}+ \\
& \sum_{t^{*}=2012}^{2017} I\left(t=t^{*}\right) \beta_{t^{*}}+u_{j, k, t}
\end{aligned}
$$

where Size $_{j, k, t}$ is the pension fund $j$ 's average assets under management in euro in asset class $k$ during year $t$ and $S_{\text {pec }} c_{j, k, t}$ represents the average allocation towards a specific asset class, measured as the allocation to asset class $k$ divided by the total assets under management. Note that the variable $\operatorname{Spec}_{j, k, t}$ is only included in the regressions at the asset class levels as specialization is not possible at the total portfolio level. This regression enables us to investigate the direct impact of pension fund size $\left(\beta_{1, k}\right)$ and specialization $\left(\beta_{2, k}\right)$ on performance fees, as well as to examine whether size and specialization influence the proportion of gross excess return a fund pays in fees $\left(\beta_{4, k}\right.$ and $\left.\beta_{5, k}\right)$.

\footnotetext{
${ }^{10}$ In practice, performance fees can also be negative due to, for instance, clawback procedures. We do not experience negative performance fees in our sample, likely because the fees run over several mandates and investment funds within an asset category. Therefore, any negative performance fee in a given mandate is likely being compensated by the positive performance fees in other mandates or investment funds within that same asset class.
} 


\subsection{Bootstrap procedure}

We have to acknowledge the possibility that our findings are driven by small-sample biases or by the non-linearity in our performance fee models, and that observed correlations between performance fees and (net) returns are therefore spurious. As a robustness check, we use a randomization-bootstrap procedure where we re-estimate all coefficients in regression models (1), (3), (4) and (5). We report the bootstrap t-statistics in all relevant tables. Following Efron (1979), we apply the following bootstrap procedure per asset category for every model:

(1) Sample with replacement the same number of observations as when estimating standard model;

(2) Store the estimated coefficients;

(3) Repeat the first two steps 5000 times;

(4) Calculate the estimated coefficients as the average of the 5000 estimated coefficients and subsequently divide this average by the standard deviation of the 5000 estimated coefficients to construct the bootstrapped t-statistic.

\section{Empirical results}

We now turn to the empirical results. In Section 4.1, we examine our first research question whether pension funds that pay performance fees are able to earn higher net total or excess returns. We analyze our second research question in Section 4.2, namely if gross total or excess return primarily drives performance fees paid. In Section 4.3 we test our final research question if large pension funds or more specialized pension funds pay less performance fees.

\subsection{Performance fees and net returns: does it pay to pay?}

Table 3 presents the main findings on whether it pays to pay performance fees for pension funds. Panel A of this table displays the results for net total returns from estimating regression (1). A key finding is that the net total returns of pension funds that pay performance fees to asset managers are not significantly higher or lower than the net returns of pension funds that do not pay performance fees. Equity is an exception, although the economic size of the finding is negligible. Pension funds that pay performance fees report 0.5 basis point lower net total return per year. The finding is statistically significant at the 5 percent level and in line with the negative relation between fees and net performance that Carhart (1997) and Fama and French (2010) document for equity mutual funds. ${ }^{11}$ Panel A also reports that pension fund size positively corresponds to net total returns for equities, real estate, private equity and hedge funds. Larger pension funds thus generate higher net total returns in most asset classes. A pension fund that is 10 times larger in terms of assets under management earns, on average, 0.66 basis point more net total return on equities. For alternative asset classes, this is stronger and ranges between 1.40 and 2.45 basis points more. A possible explanation is economies of scale. Furthermore, we find that specialization positively correlates with all asset classes, expect for commodities.

Table 3, Panel B shows the estimation results of (1) for net excess returns. We find that pension funds that pay performance fees report a higher net excess return for hedge funds than pension funds that pay no fees. A pension fund that pays performance fees, on average, earns 2.30 basis points more net excess return in hedge funds. The result is statistically significant at the 5 percent level and in line with the majority of academic studies (e.g., Agarwal et al., 2009), although it should be noted that we measure excess return as the return over the benchmark that is self-selected by the pension fund. Nevertheless, paying performance fees apparently enables pension funds to incentivize hedge fund managers in realizing a higher net return. Panel B also reports that pension fund size positively relates to net excess returns for fixed income and equities. A pension fund that is 10 times larger in terms of assets under management earns, for instance, shows 0.41 basis points more net excess equity return. Specialization only has a positive effect on the net excess hedge funds returns. If a pension funds allocates 1 percentage points more to hedge funds, it reports 0.88 basis point more net excess return on hedge funds.

\subsection{Drivers of performance fees: gross excess or gross total return?}

Table 4 presents the results of our analysis in regression (3) where we examine what type of return drives performance fees. Panel A displays the relation between performance fees and gross excess returns for the total portfolio as well as for the six asset classes. The row 'excess return' reports the annual amount of performance fees that pension funds pay for a gross excess return of 100 basis points, given that they pay (positive) performance fees. Our main finding from this panel is that performance fees are directly linked to gross excess returns for equities, real estate and hedge funds. For hedge funds, pension funds pay 29.10 basis points of performance fee for every 100 basis points of gross excess return. This is statistically significant at the 1 percent level and implies that performance fee constitute about 30 percent of the generated excess return by hedge funds. For equities and real estate, this ratio is substantially lower at 2.1 percent, given that they pay positive performance fees.

\footnotetext{
${ }^{11}$ It is not possible to directly compare our findings with Andonov et al. (2012) because the research questions are different. Andonov et al. (2012) analyze the whether pension funds outperform self-reported benchmarks. Our research question is to what extend the group of pension funds that pay performance fees earn a higher net (excess) return compared to the group of pension funds that does not. Strictly speaking the latter group consists of passive investors and active investors that realized an underperformance and as a consequence did not pay performance fees.
} 
Table 3

Performance fees and net returns: does it pay to pay?

\begin{tabular}{|c|c|c|c|c|c|c|c|}
\hline \multicolumn{8}{|c|}{ Panel A: Net Total Return } \\
\hline & Total Portfolio & Fixed Income & Equities & Real Estate & Private Equity & Hedge Funds & Commodities \\
\hline Paying fees & $\begin{array}{l}-0.16 \\
(-0.20) \\
{[-0.12]}\end{array}$ & $\begin{array}{l}-0.15 \\
(-0.50) \\
{[-0.52]}\end{array}$ & $\begin{array}{l}-0.50^{* *} \\
(-2.25) \\
{[-2.21]}\end{array}$ & $\begin{array}{l}-0.66 \\
(-1.43) \\
{[-1.64]}\end{array}$ & $\begin{array}{l}1.04 \\
(0.60) \\
{[0.52]}\end{array}$ & $\begin{array}{l}0.92 \\
(0.61) \\
{[0.49]}\end{array}$ & $\begin{array}{l}0.02 \\
(0.14) \\
{[0.20]}\end{array}$ \\
\hline Log size & $\begin{array}{l}0.01 \\
(0.07) \\
{[0.03]}\end{array}$ & $\begin{array}{l}0.21 \\
(1.02) \\
{[0.85]}\end{array}$ & $\begin{array}{l}0.66^{* * *} \\
(4.09) \\
{[4.23]}\end{array}$ & $\begin{array}{l}1.40^{* * *} \\
(4.94) \\
{[4.17]}\end{array}$ & $\begin{array}{l}2.45^{* *} \\
(2.40) \\
{[2.33]}\end{array}$ & $\begin{array}{l}1.89^{* * *} \\
(2.58) \\
{[2.44]}\end{array}$ & $\begin{array}{l}0.77 \\
(1.17) \\
{[1.13]}\end{array}$ \\
\hline Specialization & & $\begin{array}{l}0.03^{*} \\
(1.68) \\
{[1.97]}\end{array}$ & $\begin{array}{l}0.02^{*} \\
(1.92) \\
{[1.72]}\end{array}$ & $\begin{array}{l}0.27^{* * *} \\
(4.23) \\
{[4.15]}\end{array}$ & $\begin{array}{l}0.64^{* *} \\
(1.98) \\
{[2.25]}\end{array}$ & $\begin{array}{l}1.31^{* * * *} \\
(5.08) \\
{[4.71]}\end{array}$ & $\begin{array}{l}-0.48 \\
(-1.42) \\
{[-1.39]}\end{array}$ \\
\hline $\begin{array}{l}\mathrm{N} \\
\mathrm{R}^{2}\end{array}$ & $\begin{array}{l}1015 \\
0.94\end{array}$ & $\begin{array}{l}1015 \\
0.90\end{array}$ & $\begin{array}{l}1015 \\
0.61\end{array}$ & $\begin{array}{l}848 \\
0.45\end{array}$ & $\begin{array}{l}339 \\
0.17\end{array}$ & $\begin{array}{l}195 \\
0.30\end{array}$ & $\begin{array}{l}261 \\
0.64\end{array}$ \\
\hline \multicolumn{8}{|c|}{ Panel B: Net Excess Return } \\
\hline & Total Portfolio & Fixed Income & Equities & Real Estate & Private Equity & Hedge Funds & Commodities \\
\hline Paying fees & $\begin{array}{l}-0.15 \\
(-1.14) \\
{[-1.29]}\end{array}$ & $\begin{array}{l}0.12 \\
(0.54) \\
{[0.95]}\end{array}$ & $\begin{array}{l}0.14 \\
(0.51) \\
{[0.57]}\end{array}$ & $\begin{array}{l}0.04 \\
(0.15) \\
{[0.14]}\end{array}$ & $\begin{array}{l}-1.15 \\
(-0.72) \\
{[-0.68]}\end{array}$ & $\begin{array}{l}2.30^{* *} \\
(1.98) \\
{[1.97]}\end{array}$ & $\begin{array}{l}-0.07 \\
(-0.14) \\
{[-0.27]}\end{array}$ \\
\hline Log size & $\begin{array}{l}0.11 \\
(1.00) \\
{[1.01]}\end{array}$ & $\begin{array}{l}0.20^{* *} \\
(2.00) \\
{[2.20]}\end{array}$ & $\begin{array}{l}0.41^{* * * *} \\
(4.10) \\
{[4.83]}\end{array}$ & $\begin{array}{l}0.24 \\
(1.16) \\
{[1.60]}\end{array}$ & $\begin{array}{l}1.70^{*} \\
(1.68) \\
{[1.65]}\end{array}$ & $\begin{array}{l}0.69 \\
(1.10) \\
{[1.05]}\end{array}$ & $\begin{array}{l}0.60 \\
(1.51) \\
{[2.09]}\end{array}$ \\
\hline Specialization & & $\begin{array}{l}0.01 \\
(1.01) \\
{[0.99]}\end{array}$ & $\begin{array}{l}-0.01 \\
(-0.58) \\
{[-0.57]}\end{array}$ & $\begin{array}{l}0.01 \\
(0.26) \\
{[0.25]}\end{array}$ & $\begin{array}{l}0.20 \\
(0.46) \\
{[0.54]}\end{array}$ & $\begin{array}{l}0.88^{* * * *} \\
(4.14) \\
{[4.03]}\end{array}$ & $\begin{array}{l}0.15 \\
(0.80) \\
{[1.02]}\end{array}$ \\
\hline $\mathrm{N}$ & 1015 & 1015 & 1015 & 848 & 339 & 195 & 261 \\
\hline $\mathrm{R}^{2}$ & 0.03 & 0.03 & 0.04 & 0.02 & 0.07 & 0.21 & 0.05 \\
\hline
\end{tabular}

Table 3 displays the results of the panel regressions (1) that investigate whether paying performance fees contributes to net investment returns for 218 pension funds from 2012 to 2017. Panel A presents the outcome for total net return, whereas Panel B displays the results for net excess return. The row 'Paying Fees' reports the coefficients for a dummy which is 1 for pension funds that paid performance fees in the previous year and 0 otherwise. All results are reported at the total portfolio level as well as for six asset classes, namely fixed income, equities, real estate, private equity, hedge funds and commodities. The economic coefficients are measured as annual basis points, whereas the first number under the coefficient in brackets reports the tstatistic. The numbers in square brackets are the conditional bootstrap t-statistics. ${ }^{* * *},{ }^{* * *}$ represent the statistical significance at the 10 percent, 5 percent and 1 percent level, using the most strict outcome between the t-statistic and bootstrap t-statistic. We use White standard errors to correct for heteroskedasticity. The table also reports the number of observations in the sample (N) and the $\mathrm{R}^{2}$.

Table 4, Panel B reports the results when we also include the gross total return in the analysis. The gross total return is a proxy for the market return. We find a statistically significant (at the 1 percent level) relation between performance fees and gross total returns for all alternative asset classes, namely real estate, private equity, hedge funds and commodities. For hedge funds, pension funds appear to pay both for net total and excess return. Pension funds that pay performance fees, on average pay respectively 6.51 and 22.70 basis points of performance fees for every 100 basis points in additional total and excess return for hedge funds. So while pension funds pay approximately 23 percent of their excess return on fees, this is about 7 percent for total returns. Interestingly, performance fees for private equity investments appear related to gross total return, but not to gross excess return. Pension funds, on average, pay 6.79 basis points on fees for every 100 basis points in gross total return. A possible explanation for the significant relation between performance fees and gross total returns could be that pension funds have investment mandates for private equity that contain (fixed) hurdle rates instead of focus on outperforming some benchmark. Metrick and Yasuda (2010), for instance, find that hurdle rates are highly prevalent among buyout funds.

\subsection{Drivers of performance fees: size and specialization}

Next we test whether pension fund size and the level of specialization in their investment portfolio impact the amount of performance fees that pension funds pay per basis point of excess return. Table 5 presents the results for the impact of pension fund size and specialization on the relation between performance fees and gross excess returns. We document several interesting results.

First, large pension funds appear to pay higher performance fees. This is statistically significant at the 1 percent level for the total portfolio as well as for fixed income, equities, real estate and hedge funds. However, we also find that large pension funds appear to pay less performance fees per basis point of gross excess return for hedge funds (see row 'Excess returns* Log size' in Table 5). A tenfold increase in pension fund's investments in hedge funds, for instance, corresponds with 6.22 basis points lower performance fees per 100 basis points in gross excess return. We therefore conclude that large pension funds are able to realize more profitable mandates with their asset managers than smaller pension funds. This is possibly the result of better negotiation power due to their large scale. 
Table 4

Drivers of performance fees: gross excess or gross total return?

\begin{tabular}{|c|c|c|c|c|c|c|c|}
\hline \multicolumn{8}{|c|}{ Panel A: Gross Excess Return } \\
\hline & Total Portfolio & Fixed Income & Equities & Real Estate & Private Equity & Hedge Funds & Commodities \\
\hline Excess return & $\begin{array}{l}0.32 \\
(1.41) \\
{[1.48]}\end{array}$ & $\begin{array}{l}-0.20 \\
(-1.12) \\
{[-1.05]}\end{array}$ & $\begin{array}{l}2.10^{* * * *} \\
(2.84) \\
{[2.74]}\end{array}$ & $\begin{array}{l}2.12^{* *} \\
(2.32) \\
{[2.33]}\end{array}$ & $\begin{array}{l}1.50 \\
(0.93) \\
{[0.95]}\end{array}$ & $\begin{array}{l}29.10^{* * *} \\
(4.92) \\
{[4.65]}\end{array}$ & $\begin{array}{l}0.94 \\
(1.33) \\
{[1.24]}\end{array}$ \\
\hline $\begin{array}{l}\mathrm{N} \\
\mathrm{R}^{2}\end{array}$ & $\begin{array}{l}1231 \\
0.22\end{array}$ & $\begin{array}{l}1231 \\
0.42\end{array}$ & $\begin{array}{l}1231 \\
0.23\end{array}$ & $\begin{array}{l}1039 \\
0.40\end{array}$ & $\begin{array}{l}417 \\
0.28\end{array}$ & $\begin{array}{l}266 \\
0.46\end{array}$ & $\begin{array}{l}367 \\
0.77\end{array}$ \\
\hline \multicolumn{8}{|c|}{ Panel B: Gross Excess Return and Gross Total Return } \\
\hline & Total Portfolio & Fixed Income & Equities & Real Estate & Private Equity & Hedge Funds & Commodities \\
\hline Excess return & $\begin{array}{l}0.04 \\
(0.07) \\
{[0.42]}\end{array}$ & $\begin{array}{l}-0.19 \\
(-1.01) \\
{[-0.95]}\end{array}$ & $\begin{array}{l}2.01^{* * * *} \\
(2.75) \\
{[2.64]}\end{array}$ & $\begin{array}{l}1.73^{* *} \\
(2.05) \\
{[2.08]}\end{array}$ & $\begin{array}{l}2.63 \\
(1.35) \\
{[1.28]}\end{array}$ & $\begin{array}{l}22.70^{* * *} \\
(4.03) \\
{[3.83]}\end{array}$ & $\begin{array}{l}0.58 \\
(1.02) \\
{[0.97]}\end{array}$ \\
\hline Total return & $\begin{array}{l}0.12 \\
(1.27) \\
{[1.33]}\end{array}$ & $\begin{array}{l}0.04 \\
(0.58) \\
{[0.57]}\end{array}$ & $\begin{array}{l}0.17 \\
(0.51) \\
{[0.47]}\end{array}$ & $\begin{array}{l}0.44^{*} \\
(1.74) \\
{[1.72]}\end{array}$ & $\begin{array}{l}6.79^{* * *} \\
(4.33) \\
{[4.41]}\end{array}$ & $\begin{array}{l}6.51^{* * *} \\
(3.44) \\
{[3.19]}\end{array}$ & $\begin{array}{l}2.33^{* *} \\
(2.32) \\
{[2.25]}\end{array}$ \\
\hline $\mathrm{N}$ & 1231 & 1231 & 1231 & 1039 & 417 & 266 & 367 \\
\hline $\mathrm{R}^{2}$ & 0.20 & 0.42 & 0.24 & 0.42 & 0.37 & 0.47 & 0.80 \\
\hline
\end{tabular}

Table 4 presents the results of Tobit panel regressions in (3) and (4) to examine what investment returns are driving performance fees of 218 pension funds during the full sample period (2012-2017). We perform two regressions to investigate different return targets. Panel A presents the results when we relate performance fees to gross excess returns and Panel B reports the results when we include both gross total and gross excess returns for a pension fund. We present the results for the total portfolio level as well as for six asset classes, namely fixed income, equities, real estate, private equity, hedge funds and commodities. The coefficients for the yearly dummies are not reported in the interest of brevity. The economic coefficients are measured as annual basis points, whereas the number under the coefficient in brackets reports the z-statistic. The numbers in square brackets are the conditional bootstrap zstatistics. ${ }^{* * * * * * *}$ represent the statistical significance at the 10 percent, 5 percent and 1 percent level, using the most strict outcome between the $z$-statistic and bootstrap z-statistic. We use White standard errors to correct for heteroskedasticity. The table also reports the number of observations in the sample $(\mathrm{N})$ and the $\mathrm{R}^{2}$.

Table 5

Drivers of performance fees: size and specialization.

\begin{tabular}{|c|c|c|c|c|c|c|c|}
\hline \multicolumn{8}{|c|}{ Pension Fund Size and Specialization } \\
\hline & Total Portfolio & Fixed Income & Equities & Real Estate & Private Equity & Hedge Funds & Commodities \\
\hline Log size & $\begin{array}{l}0.07^{* * *} \\
(9.73) \\
{[9.32]}\end{array}$ & $\begin{array}{l}0.04^{* * *} \\
(5.06) \\
{[4.81]}\end{array}$ & $\begin{array}{l}0.07^{* * *} \\
(4.32) \\
{[4.09]}\end{array}$ & $\begin{array}{l}0.08^{* * *} \\
(3.66) \\
{[3.43]}\end{array}$ & $\begin{array}{l}0.07 \\
(0.82) \\
{[0.82]}\end{array}$ & $\begin{array}{l}0.67^{* * *} \\
(4.73) \\
{[3.61]}\end{array}$ & $\begin{array}{l}0.02 \\
(1.27) \\
{[0.98]}\end{array}$ \\
\hline Specialization & & $\begin{array}{l}-0.13 \\
(-1.51) \\
{[-1.49]}\end{array}$ & $\begin{array}{l}0.08 \\
(0.50) \\
{[0.48]}\end{array}$ & $\begin{array}{l}0.47 \\
(1.07) \\
{[1.15]}\end{array}$ & $\begin{array}{l}34.04^{* * * *} \\
(5.67) \\
{[5.50]}\end{array}$ & $\begin{array}{l}5.78 \\
(1.10) \\
{[0.93]}\end{array}$ & $\begin{array}{l}4.31^{* *} \\
(2.06) \\
{[1.97]}\end{array}$ \\
\hline Excess return & $\begin{array}{l}0.20 \\
(0.10) \\
{[0.08]}\end{array}$ & $\begin{array}{l}0.09 \\
(0.65) \\
{[0.70]}\end{array}$ & $\begin{array}{l}0.48 \\
(0.83) \\
{[0.78]}\end{array}$ & $\begin{array}{l}1.63 \\
(1.56) \\
{[1.31]}\end{array}$ & $\begin{array}{l}0.29 \\
(0.30) \\
{[0.33]}\end{array}$ & $\begin{array}{l}21.61^{* * *} \\
(6.02) \\
{[3.36]}\end{array}$ & $\begin{array}{l}0.36 \\
(0.73) \\
{[0.72]}\end{array}$ \\
\hline Excess return*Log size & $\begin{array}{l}0.12 \\
(0.44) \\
{[0.21]}\end{array}$ & $\begin{array}{l}-0.11 \\
(-0.25) \\
{[-0.04]}\end{array}$ & $\begin{array}{l}-1.08 \\
(-0.85) \\
{[-0.87]}\end{array}$ & $\begin{array}{l}-0.42^{*} \\
(-1.77) \\
{[-1.75]}\end{array}$ & $\begin{array}{l}0.15 \\
(0.72) \\
{[0.59]}\end{array}$ & $\begin{array}{l}-6.22^{* *} \\
(-2.05) \\
{[-1.97]}\end{array}$ & $\begin{array}{l}0.11 \\
(0.98) \\
{[1.01]}\end{array}$ \\
\hline Excess return*Specialization & & $\begin{array}{l}0.02 \\
(1.04) \\
{[0.90]}\end{array}$ & $\begin{array}{l}0.09 \\
(0.81) \\
{[0.65]}\end{array}$ & $\begin{array}{l}-0.04 \\
(-1.32) \\
{[-1.27]}\end{array}$ & $\begin{array}{l}-0.32^{* * *} \\
(-4.41) \\
{[-3.85]}\end{array}$ & $\begin{array}{l}-0.30^{* *} \\
(-2.72) \\
{[-2.48]}\end{array}$ & $\begin{array}{l}-0.04 \\
(-0.58) \\
{[-0.62]}\end{array}$ \\
\hline $\mathrm{N}$ & 1231 & 1231 & 1231 & 1039 & 417 & 266 & 367 \\
\hline $\mathrm{R}^{2}$ & 0.38 & 0.62 & 0.39 & 0.65 & 0.45 & 0.60 & 0.85 \\
\hline
\end{tabular}

Table 5 presents the results of Tobit panel regressions in (5) to examine whether pension fund size and level of specialization in their investment portfolio influence the relation between performance fees and excess returns for 218 pension funds during the sample period (2012-2017). We present the results for the total portfolio level as well as for six asset classes. The coefficients for the yearly dummies are not reported in the interest of brevity. The economic coefficients are measured as annual basis points, whereas the number under the coefficient in brackets reports the z-statistic and the numbers in square brackets are the conditional bootstrap z-statistics. ", ${ }^{* *},{ }^{* * *}$ represent the statistical significance at the 10 percent, 5 percent and 1 percent level, using the most strict outcome between the z-statistic and bootstrap z-statistic. We use White standard errors to correct for heteroskedasticity. The table also reports the number of observations in the sample $(\mathrm{N})$ and the $\mathrm{R}^{2}$.

Second, more specialized pension funds, i.e. those that invest a higher proportion of their assets in one specific asset class, appear to pay significantly more performance fees for private equity and commodities. Table 5 reports that increasing the allocation towards these asset classes with one percentage point leads to respectively 34.04 and 4.31 basis points more performance fees. More specialized pension funds, however, appear to pay a smaller proportion of their gross excess returns on performance fees for alternative asset classes (see row 'Excess returns*Specialization' in Table 5). Pension funds that increase 
their allocation to private equity with 1 percentage point, for example, pay 0.32 basis point less fees per 100 basis points gross excess return. For hedge funds, this reduction is 0.30 basis point. Apparently, higher specialized pension funds have more power to negotiate lower fees per basis point of excess return for private equity and hedge funds.

\section{Robustness checks}

In addition to the randomized bootstrap procedure we also employ several robustness checks. For one, we perform the analysis on risk-adjusted net returns. In addition, it is important to note that our dataset contains information on performance fees at the aggregate asset class level, but not on individual investment mandates. We therefore also examine the possible impact of this inherent limitation on our main findings.

\subsection{Controlling for risk}

It is important to assess risk-adjusted returns when analyzing pension fund performance. Bauer et al. (2010) argue that this is the case because benchmarks are typically chosen by the pension funds themselves, thereby creating an incentive to choose benchmarks that are relatively easy to beat. As a robustness check, we risk-adjust the net returns by including the volatility of net returns in our main regression model (1). Our dataset contains annual as well as quarterly investment returns for all asset classes. We use the latter to construct a variable for volatility $\left(V O L_{j, k, t}\right)$ which represents the annualized standard deviation of the four quarterly net total or net excess returns in year $t$. As such, we run the following regression where we explain the net investment returns $R$ for pension fund $j$ in year $t$ :

$$
\begin{aligned}
& R_{j, k, t}=\beta_{1} \text { Paying Fees }_{j, k, t-1}+\beta_{2} \log \left(\text { Size }_{j, k, t}\right)+\beta_{3} \text { Spec }_{j, k, t}+\beta_{4} V O L_{j, k, t}+ \\
& \sum_{t^{*}=2013}^{2017} I\left(t=t^{*}\right)\left(\beta_{5, t^{*}} \mathrm{DUR}_{F I . j, k, t}+\beta_{6, t^{*}} \mathrm{DUR}_{0, j, k, t}+X_{j, k, t} \beta_{7, t^{*}}+Y_{j, k, t} \beta_{8, t^{*}}\right)+\varepsilon_{j, k, t}
\end{aligned}
$$

where all variables are defined in a similar manner as in regression model (1).

Table 6 displays the results for risk-adjusted net total returns (Panel A) as well as net excess returns (Panel B). We document several interesting findings. For one, risk appears to be an important driver for both net total and excess returns as the 'volatility of returns' coefficient is statistically significant for most asset classes. ${ }^{12}$ In addition, we observe that our key finding is robust. After risk-adjustment, we find that the total returns of pension funds that pay performance fees to asset managers are not significantly higher or lower than the returns of pension funds that do not pay performance fees. We also still observe a significant negative relation between paying performance fees and net total return for equities. Note that after adjusting for risk, we also find a negative relation between paying performance fees and private equity returns, although this finding is only statistically significant at the 10 percent level. Finally, Panel B of Table 6 shows that we no longer find that pension funds that pay performance fees report a higher net excess return for hedge funds after correcting for risk.

\subsection{Controlling for individual investment mandates}

Although our dataset is free from self-reporting biases and highly detailed, it contains an important limitation as our dataset contains information at the aggregate asset class level, but not for individual investment mandates. As such, the data on returns and performance fees per asset class represent the aggregate return over the individual mandates and the sum of the performance fees paid over different mandates. This may influence our results when we examine performance fees as pension funds typically employ different mandates within one asset class. Take for instance a pension fund that invests in two different hedge fund mandates. The pension fund may realize a positive return on the first mandate and a negative return on the second mandate, which may result in an aggregate return of approximately 0 for hedge funds. As the pension fund will probably pay performance fees for the first mandate (given the positive return), this would result in the pension fund paying a positive performance fee for a return close to 0 at the asset class level. To analyse the impact of this data limitation on our findings, we perform an unreported simulation study. ${ }^{13}$ We find that as a result of the aggregate nature of our data, we tend to underestimate the economic effect of our findings and then to overestimate the standard errors at the aggregate asset class level. Therefore, it is possible that the relation between performance fees and net returns in Table 3 is actually (more) economically and statistically significant for more asset classes than we observe. Although this is a bias inherent in our dataset, we note that it is a conservative one in nature.

\footnotetext{
12 We find a negative coefficient for hedge funds and commodities. The latter can be explained by the nearly persistently negative returns for commodities during our sample period. A possible explanation for hedge funds stems from the great variation in hedge fund strategies, also demonstrated by the large crosssectional variation in the hedge fund returns in the different years. Also volatility is not the best measure of hedge fund returns as those are often skewed.

${ }^{13}$ In the simulation study we consider the following model for the returns and performance fees of pension fund $j$ at time $t$ for its mandate or investment fund l: $P F_{j, t, l}^{*}=\alpha+\beta \times I\left(R_{j, t, l}>0\right) R_{j, t, l}$ with $R_{j, t, l} N(\mu, \sigma)$, and $P F_{j, t}^{*}=\sum_{l} P F_{j, t, l}^{*}$ and $R_{j, t}=\sum_{l} R_{j, t, l}$, where we set $\alpha$ at 0 , while $\beta$ represents the average ratio of performance fees paid over total gross return which we set at 20 percent. In addition, $\mu$ is the expected return for an individual mandate which we determine as 0 and $\sigma$ is the standard deviation which we set at 10 percent. We then estimate the relation between the aggregate performance fees $P F_{j, t}^{*}$ and returns $R_{j, t}$ : $P F_{j, t}^{*}=\alpha^{*}+\beta^{*} \times I\left(R_{j, t}>0\right) R_{j, t}+\varepsilon_{j, t}$. The standard deviation of $\varepsilon_{j, t}$ can be considered as the additional standard error due to the aggregation of the individual mandates to the asset class level that we report. As a result, the difference between $\beta^{*}$ and $\beta$ represents the bias in our model for the percentage of net total or net excess return that pension funds pay in performance fees. The results are not reported in the interest of brevity, but are available upon request.
} 
Table 6

Performance Fees and Net Returns: Does it Pay to Pay after Risk-Adjustment?

\begin{tabular}{|c|c|c|c|c|c|c|c|}
\hline \multicolumn{8}{|c|}{ Panel A: Net Total Return } \\
\hline & Total Portfolio & Fixed Income & Equities & Real Estate & Private Equity & Hedge Funds & Commodities \\
\hline \multirow[t]{3}{*}{ Paying fees } & 0.01 & -0.26 & $-0.42^{* *}$ & -0.38 & $-2.60^{*}$ & -0.22 & 0.29 \\
\hline & $(0.22)$ & $(-0.52)$ & $(-1.99)$ & $(-0.94)$ & $(-2.30)$ & $(-0.14)$ & $(0.23)$ \\
\hline & {$[0.12]$} & {$[-0.55]$} & {$[-1.98]$} & {$[-0.93]$} & {$[-1.78]$} & {$[-0.22]$} & {$[0.25]$} \\
\hline \multirow[t]{3}{*}{ Log size } & 0.02 & 0.12 & $0.54^{* * *}$ & $1.21^{* * *}$ & 1.03 & $2.81^{* * * *}$ & $1.88^{* * * *}$ \\
\hline & $(0.05)$ & $(0.77)$ & (3.95) & $(4.70)$ & $(1.42)$ & $(4.34)$ & $(2.86)$ \\
\hline & [0.09] & {$[0.22]$} & [4.04] & [4.91] & [1.57] & [3.82] & [2.83] \\
\hline \multirow[t]{3}{*}{ Specialization } & & 0.03 & 0.02 & $0.18^{* * *}$ & $0.73^{* * *}$ & $1.07^{* * * *}$ & -0.05 \\
\hline & & (1.87) & (1.93) & $(2.85)$ & $(2.50)$ & (4.53) & $(-0.15)$ \\
\hline & & [0.99] & [1.60] & [2.68] & [2.21] & [3.82] & {$[-0.11]$} \\
\hline \multirow[t]{3}{*}{ Return volatility } & 0.06 & $0.48^{* * * *}$ & $0.59^{* * *}$ & $0.46^{* * * *}$ & 0.16 & $-0.79^{* * *}$ & -0.93 \\
\hline & $(0.94)$ & (3.51) & $(4.94)$ & $(6.07)$ & $(0.91)$ & $(-4.01)$ & $(-2.71)$ \\
\hline & {$[1.22]$} & [3.21] & {$[3.04]$} & {$[4.12]$} & {$[0.87]$} & {$[-3.68]$} & {$[-1.08]$} \\
\hline $\mathrm{N}$ & 1015 & 1015 & 1015 & 848 & 339 & 195 & 261 \\
\hline $\mathrm{R}^{2}$ & 0.94 & 0.90 & 0.62 & 0.50 & 0.63 & 0.50 & 0.72 \\
\hline \multicolumn{8}{|c|}{ Panel B: Net Excess Return } \\
\hline & Total Portfolio & Fixed Income & Equities & Real Estate & Private Equity & Hedge Funds & Commodities \\
\hline \multirow[t]{3}{*}{ Paying fees } & -0.18 & 0.07 & 0.09 & -0.07 & $-2.46^{*}$ & 0.58 & -0.09 \\
\hline & $(-0.88)$ & $(0.21)$ & $(0.62)$ & $(-0.26)$ & $(-2.31)$ & $(0.62)$ & $(-0.10)$ \\
\hline & {$[-1.01]$} & {$[0.37]$} & [0.70] & {$[-0.12]$} & {$[-1.80]$} & [0.47] & {$[-0.20]$} \\
\hline \multirow[t]{3}{*}{ Log size } & 0.14 & 0.12 & $0.44^{* * *}$ & 0.24 & $1.18^{*}$ & $0.92^{*}$ & 0.66 \\
\hline & (1.14) & (0.99) & (4.33) & $(1.21)$ & (1.77) & (1.75) & (1.49) \\
\hline & [1.20] & [1.21] & [4.62] & [1.57] & [1.94] & [1.98] & [1.92] \\
\hline \multirow[t]{3}{*}{ Specialization } & & 0.01 & -0.01 & 0.20 & -0.50 & $0.45^{* * * *}$ & 0.16 \\
\hline & & (0.59) & $(-0.65)$ & $(0.23)$ & $(-0.20)$ & (2.59) & $(0.86)$ \\
\hline & & {$[0.58]$} & {$[-0.63]$} & [0.25] & {$[0.21]$} & [2.91] & [1.13] \\
\hline \multirow[t]{3}{*}{ Return volatility } & $0.18^{* * *}$ & $-0.39^{* * *}$ & $0.19^{* *}$ & 0.14 & 0.19 & $-0.81^{* * *}$ & 0.05 \\
\hline & (2.69) & $(-4.28)$ & $(2.78)$ & (1.36) & (1.22) & $(-4.19)$ & $(0.25)$ \\
\hline & [2.16] & {$[-3.66]$} & [2.19] & [1.08] & [1.05] & {$[-3.07]$} & [0.09] \\
\hline $\mathrm{N}$ & 1015 & 1015 & 1015 & 848 & 339 & 195 & 261 \\
\hline $\mathrm{R}^{2}$ & 0.03 & 0.07 & 0.05 & 0.02 & 0.57 & 0.48 & 0.05 \\
\hline
\end{tabular}

Table 6 displays the results of the panel regressions in (6) that investigate whether paying performance fees contributes to investment returns for 218 pension funds during the years 2012-2017 when adjusting for total risk. Panel A presents the outcome for total net return, whereas Panel B displays the results for net excess return. The row 'Paying Fees' reports the coefficients for a dummy which is 1 for pension funds that paid performance fees in the previous year and 0 otherwise. All results are reported at the total portfolio level as well as for six asset classes. The economic coefficients are measured as annual basis points, whereas the first number under the coefficient in brackets reports the t-statistic. The numbers in square brackets are the conditional bootstrap t-statistics. ${ }^{*},{ }^{* *},{ }^{* * *}$ represent the statistical significance at the 10 percent, 5 percent and 1 percent level, using the most strict outcome between the t-statistic and bootstrap t-statistic. We use White standard errors to correct for heteroskedasticity. The table also reports the number of observations in the sample $(\mathrm{N})$ and the $\mathrm{R}^{2}$.

\section{Conclusions}

This paper provides a comprehensive analysis of the relation between investment returns and performance fees for all Dutch occupational pension funds. Our dataset is free from self-reporting biases and includes risk-adjusted net total and excess returns as well as performance fees per pension fund. We are able to distinguish returns and fees for the total portfolio level as well as for six separate asset classes. Our key findings are as follows.

First, we find that the net (after-fees) returns of pension funds that pay performance fees to asset managers are not significantly higher or lower than the net returns of pension funds that do not pay performance fees. The findings are robust after controlling for risk. There is, however, one exception. For hedge funds, we find that pension funds that pay performance fees report, on average, 2.3 basis points more net excess return. The statistical significance, however, disappears when we adjust for risk. Second, we document that specialization is positively related to net returns for alternative asset classes such as real estate, private equity and hedge funds. In terms of net excess return, only specialization in hedge funds adds value. We also find that larger pension funds have a significantly higher net total return for most asset classes.

Third, performance fees are directly linked to gross excess returns for equities, real estate and hedge funds. For private equity, on the other hand, gross total return appears the main driver for performance fees. A possible explanation for this is that pension funds have investment mandates for private equity that focus on realizing a (fixed) hurdle rate. Fourth, we find that large and more specialized pension funds are able to realize more profitable mandates with their asset managers, possibly as a result of better negotiation power due to their large scale or high level of expertise. A tenfold increase in hedge fund investments, for instance, corresponds to 6.2 basis points less performance fees per 100 basis points in gross excess return. Regarding specialization, we find a significant effect for private equity and hedge funds. Pension funds with a 1 percentage point higher allocation to private equity pay 0.32 basis point less fees per 100 basis points gross excess return. For 
hedge funds, this reduction is 0.30 basis points. The results show that pension fund size and specialization are economically more important for net returns than paying performance fees. The impact of size and specialization is notably true for alternative asset classes. Although our dataset is highly detailed, it is important to note that we are not able to investigate the relation between fees and return at the individual mandate level. To further strengthen our findings it would be helpful to have detailed knowledge on each specific mandate.

\section{References}

Andonov, A., Bauer, R.M.M.J., Cremers, K.J.M., 2012. Can large pension funds beat the market? Asset allocation, market timing, security selection and the limits of liquidity. Maastricht University Working paper.

Ackermann, C., McEnally, R., Ravenscraft, D., 1999. The performance of hedge funds: risk, return, and incentives. J. Financ. 54 (3), $833-874$.

Agarwal, V., Daniel, N.D., Naik, N.Y., 2009. Role of managerial incentives and discretion in hedge fund performance. J. Financ. 64 (5), $2221-2256$.

Bauer, R.M.M.J., Cremers, K.J.M., Frehen, R.G.P., 2010. Pension fund performance and costs: small is beautiful. Maastricht University Working paper.

Barber, B.M., Odean, T., Zheng, L., 2005. Out of sight, out of mind: the effects of expenses on mutual fund flows. J. Bus. 78 (6), $2095-2119$.

Beebower, G., Bergstrom, G., 1977. A performance analysis of pension and profit-sharing portfolios: 1966-1975. Financ. Anal. J. 33, 21-42.

Bikker, J.A., Spierdijk, L., van der Sluis, P.J., 2007. Market impact costs of institutional equity trades. J. Int. Money Financ. 26 (6), $974-1000$.

Bikker, J.A., De Dreu, J., 2009. Operating costs of pension funds: the impact of scale, governance and plan design. J. Pensions Econ. Financ., 863-889

Blake, D., Lehmann, B.N., Timmermann, A., 1999. Asset allocation dynamics and pension fund performance. J. Bus. 72 (4), $429-461$.

Blake, D., Rossi, A.G., Timmermann, A., Tonks, I., Wermers, R., 2013. Decentralized investment management: evidence from the pension fund industry. J. Financ. 68, 1133-1178.

Broeders, D.W.G.A., van Oord, A., Rijsbergen, D.R., 2016. Scale economies in pension fund investments: a dissection of investment costs across asset classes. J. Int. Money Financ. 67, 147-171.

Broeders, D., de Haan, L., 2018. Benchmark selection and performance. DNB Working Paper, no. 603.

Brown, S.J., Goetzmann, W.N., Ibbotson, R.G., 1999. Offshore hedge funds: survival and performance 1989-1995. J. Bus. 72, 91-117.

Carhart, M., 1997. On persistence in mutual fund performance. J. Financ. 52, 57-82.

Coggin, T., Fabozzi, F., Rahman, S., 1993. The investment performance of U.S. equity pension fund managers: an empirical investigation. J. Financ. 48, 10391055.

Drago, D., Lazzari, V., Navone, M., 2010. Mutual fund incentive fees: determinants and effects. Financ. Manage. 39 (1), $365-392$.

Dyck, A. and L. Pomorski, 2011, Is bigger better? Size and performance in pension plan management, Working paper.

Efron, B., 1979. Bootstrap methods: another look at the jackknife. Ann. Stat. 7 (1), 1-26.

Elton, E.J., Gruber, M.J., Blake, C.R., 2003. Incentive fees and mutual funds. J. Financ. 58, 779-804.

Fama, E.F., French, K.R., 2010. Luck versus skill in the cross-section of mutual fund returns. J. Financ. 65 (5), $1915-1947$.

French, K.R., 2008. Presidential address: the cost of active investing. J. Financ. 63 (4), 1537-1573.

Gerritsen, M., 2016. De beleggingsrendementen van de Nederlandse pensioenfondsen. Economische en Statistische Berichten $101,340-343$.

Goetzmann, W.N., Ingersoll Jr, J.E., Ross, S.A., 2003. High water marks. J. Financ. 58 (4), 1685-1717.

Gompers, P., Lerner, J., 1999. An analysis of compensation in the U.S. venture capital partnership. J. Financ. Econ. 51, 3-44.

Huang, X., Mahieu, R.J., 2012. Performance persistence of Dutch pension funds. De Economist 160, 17-34.

Ibbotson, R.G., Chen, P., Zhu, K.X., 2011. The ABCs of hedge funds: alphas, betas and costs. Financ. Anal. J. 67 (1), $15-25$.

Indro, D.C., Jiang, C.X., Hu, M.Y., Lee, W.Y., 1999. Mutual fund performance: does fund size matter? Financ. Anal. J. 55 (3), $74-87$.

Ippolito, R.A., Turner, J.A., 1987. Turnover, fees and pension plan performance. Financ. Anal. J. 43 (6), 16-26.

Jennings, W.W., Payne, B.C., 2016. Fees eat diversification's lunch. Financ. Anal. J. 72 (2), 31-40.

Jensen, M.C., 1968. The performance of mutual funds in the period 1945-1964. J. Financ. 23, 2033-2058.

Kahn, R.N., Scanlan, M.H., Siegel, L.B., 2006. Five myths about fees. J. Portfolio Manage. 32 (3), 56-64.

Keim, D.B., Madhavan, A., 1998. The cost of institutional equity trades. Financ. Anal. J. 54 (4), 50-69.

Kosowski, R., Timmermann, A., Wermers, R., White, H., 2006. Can mutual fund "stars" really pick stocks? New evidence from a bootstrap analysis. J. Financ. $61,2551-2595$

Lakonishok, J., Shleifer, A., Vishny, R., 1992. The structure and performance of the money management industry. Brookings Pap. Econ. Activity: Macroecon., $339-391$

Malkiel, B.G., 1995. Returns from investing in equity mutual funds 1971 to 1991. J. Financ. 50, 549-572.

Malkiel, B.G., 2013. Asset management fees and the growth of finance. J. Econ. Perspect. 27 (2), 97-108.

Metrick, A., Yasuda, A., 2010. The economics of private equity funds. Rev. Financ. Stud. 23 (6), $2303-2341$.

Robinson, D.T., Sensoy, B.A., 2013. Do private equity fund managers earn their fees? Compensation, ownership, and cash flow performance. Rev. Financ. Stud. 26 (11), 2760-2797.

Sharpe, W.F., 2013. The arithmetic of investment expenses. Financ. Anal. J. 69 (2), 34-41.

Sharpe, W.F., 1991. The arithmetic of active management. Financ. Anal. J. 47 (1), 7-9.

Starks, L.T., 1987. Performance incentive fees: an agency theoretic approach. J. Financ. Quant. Anal. 22 (1), 17-32.

Willis Towers Watson, 2018, Global Pension Assets Study 2018. 